\title{
A rare complication of nasogastric tube insertion
}

\author{
Jonathan Lyske \\ Intensive Care Department, Craigavon Area Hospital, Portadown, UK
}

Correspondence to Dr Jonathan Lyske, jlyske@hotmail.com

\section{DESCRIPTION}

A 44-year-old woman with a background of a mitral valve replacement presented to the emergency department with aphasia. A CT scan of the brain demonstrated an infarction in the territory of the left middle cerebral artery. She was not suitable for thrombolysis and was admitted to the stroke ward where a nasogastric (NG) tube was passed to allow administration of her medication and nutrition. The check chest $\mathrm{x}$-ray revealed that the NG tube had passed down the right main bronchus and through the lung causing a large pneumothorax (figure 1). A surgical chest drain was then inserted and a repeat radiograph showed re-inflation of the right lung (figure 2). This case demonstrates a serious complication of a common clinical procedure through inadvertent insertion of the NG tube into the airways. Studies have reported the incidence rate of accidental insertion into the trachea and smaller airways ranges from $0.3 \%$ to $15 \%$ and is more common in the older, mentally obtunded and patients who are intubated and sedated. ${ }^{1} 2$ Confirmation of gastric placement of the NG tube through clinical examination is unreliable and it is recommended that aspiration of gastric fluid and measuring a $\mathrm{pH}<5.5$ should be obtained before commencing enteral feed. ${ }^{2} 3$ However, false positive results are possible as infected pleural or respiratory secretions can yield an acidic $\mathrm{pH}$. A chest x-ray should be performed in patients who have a negative aspirate and the high risk groups described above. ${ }^{2} 3$

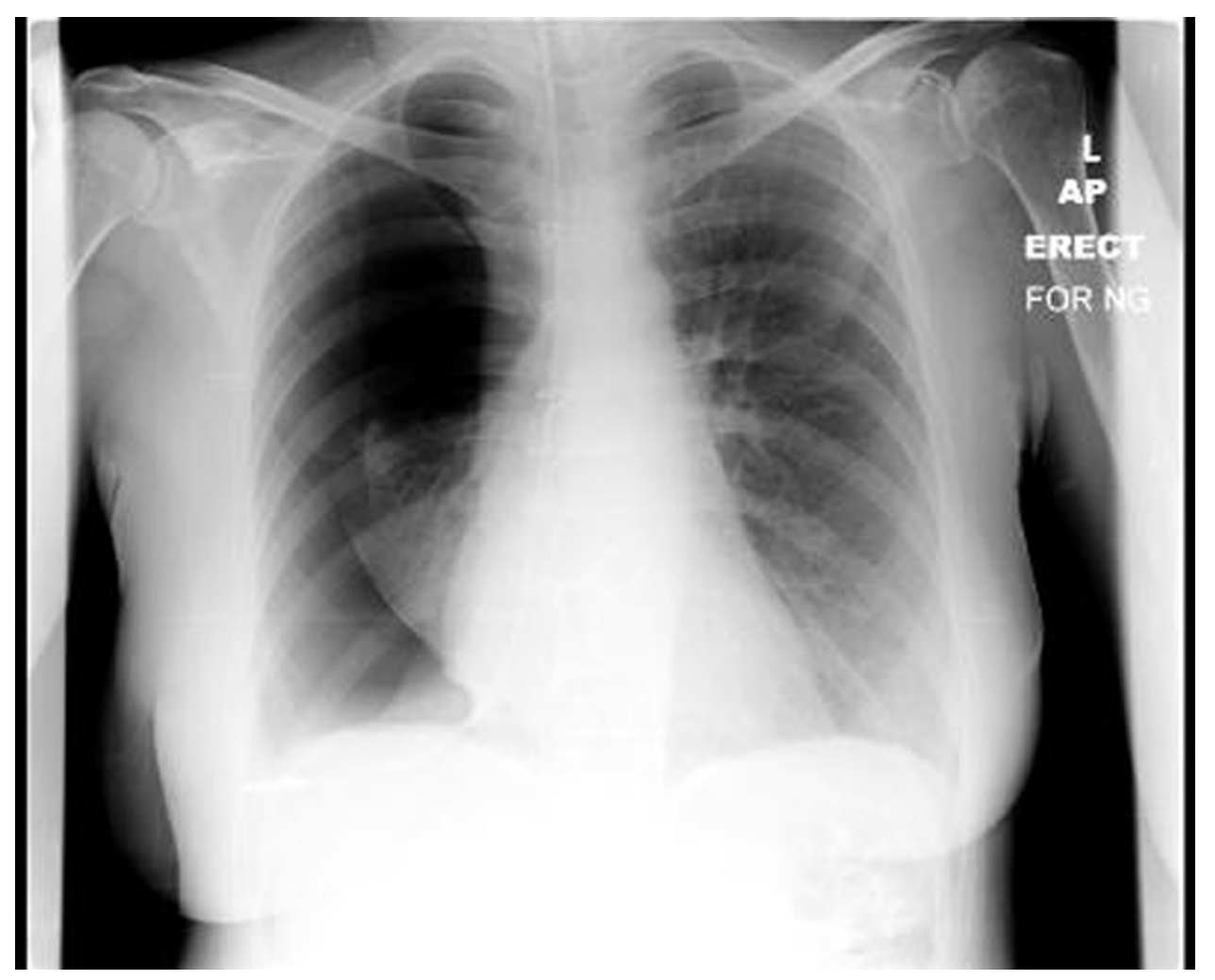

Figure 1 Nasogastric tube passed down the right main bronchus causing a large pneumothorax. 


\section{BMJ Case Reports}

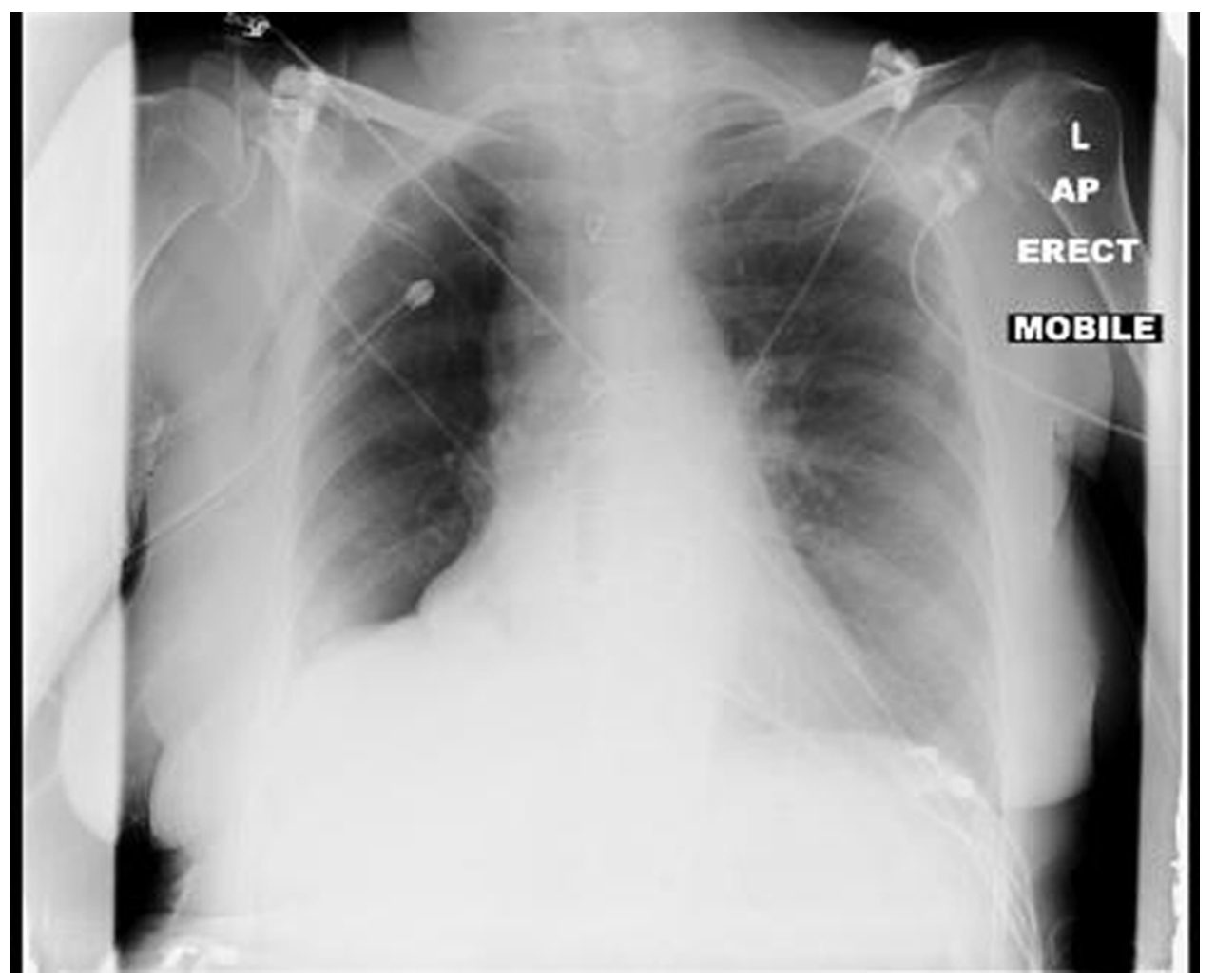

Figure 2 Re-inflation of the right lung after chest drain insertion.

\section{Competing interests None.}

Patient consent Obtained

\section{REFERENCES}

1. Rassias AJ, Ball PA, Corwin HL. A prospective study of tracheopulmonary

complications associated with the placement of narrow-bore enteral feeding tubes. Crit Care 1998;2:25-8.
2. Pillai JB, Vegas A, Brister $S$. Thoracic complications of nasogastric tube: review of safe practice. Interact Cardiovasc Thorac Surg 2005:4:429-33.

3. Nutrition support in adults. Oral Nutrition Support, Enteral Tube Feeding and Parenteral Nutrition. CG32. London: National Institute for Clinical Excellence 2006

This pdf has been created automatically from the final edited text and images.

Copyright 2011 BMJ Publishing Group. All rights reserved. For permission to reuse any of this content visit http://group.bmj.com/group/rights-licensing/permissions.

BMJ Case Report Fellows may re-use this article for personal use and teaching without any further permission.

Please cite this article as follows (you will need to access the article online to obtain the date of publication).

Lyske J. A rare complication of nasogastric tube insertion. BMJ Case Reports 2011;10.1136/bcr.08.2011.4606, date of publication

Become a Fellow of BMJ Case Reports today and you can:

- Submit as many cases as you like

- Enjoy fast sympathetic peer review and rapid publication of accepted articles

- Access all the published articles

- Re-use any of the published material for personal use and teaching without further permission

For information on Institutional Fellowships contact consortiasales@bmjgroup.com

Visit casereports.bmi.com for more articles like this and to become a Fellow 